\title{
Effect of Moringa oleifera Leaf Extract on Histopathology of Heart Tissues on Silk Dye Waste Effluent Induced Swiss Albino Male Mice Mus musculus
}

\author{
Serina Khatun*
}

University Department of Zoology, T. M. Bhagalpur University, Bhagalpur-812007, India

*Corresponding author

\section{A B S T R A C T}

\section{Keywords}

Moringa oleifera Leaf powder, Silk dye waste effluent, Histopathology, Heart tissue, Swiss albino male mice Mus musculus

\section{Article Info}

Accepted:

17 January 2018 Available Online:

10 February 2018
The present work was designed to investigate the toxic impacts of silk dye waste effluent induced on the histopathology of the heart tissue in the Swiss albino male mice Mus musculus and their mitigation using by Moringa oleifera leaf extract. Five sets of animals i.e. Group-I (Control), Group-II (fed with 50\% silk dye), Group-III (fed with $100 \%$ silk dye), Group-IV (mice fed with $50 \%$ dye treated with $M$. oleifera leaves powder), Group-V (mice fed with $100 \%$ dye treated with $M$. oleifera leaves powder) have been taken for experiment. The dose of silk dye was $2 \mathrm{ml} /$ day to both groups-II and III and M. oleifera leaf is given as per the standard dose $(300 \mathrm{mg} / \mathrm{kg}$ b.w) to both animals of group IV and V. The result was demonstrated when treated with silk dye waste showed some changes including blood vessels degeneration, disrupted endocardium, myocardium, epicardium and collagenous fibers thickness but their mitigation using Moringa oleifera leaf powder. These results, along with previous observation, suggest that $M$. oleifera may be useful in cardiac tissues damage that is a result of silk dye waste effluent toxicity.

\section{Introduction}

Moringa oleifera leaf extract is from Moringa oleifera Lamark tree. It is considered one of the world's most useful trees, as almost every part of the tree can be used for food, or has some other beneficial medicinal properties. It is commonly known as 'drumstick' and is being used as antiulcer, diuretic, antiinflammatory, anti-microbial, potentantioxidant and wound healing agent (Caceres et al., 1991; Udupa et al., 1994; Kurma and Mishra, 1998; Saalu et al., 2011 Bassey et al., 2013), pharmacological properties (Oliveira et $a l$, 1999), it's an exceptional nutritious vegetable (Ram,1994). Its leaves are used as nutritional supplement and growth promoter because of significant presence of protein, selenium, calcium, phosphorus, $\beta$-carotene and $\gamma$-tocopherol in it (Nambiar and Seshadri, 2001; Lakshminarayana et al., 2005; SanchezMachado et al., 2006).

The human are exposed to various type of environmental contaminants at different stage of their life span, widely held of them are harmful. Silk dye waste is one of the major sources of hazardous pollutants. Industrialization is a godsend of independent India but that is allied with hazardous 
effluents and discharges polluting the environment. Silk industry as textile provides an important economic stand to the artisans but the dye waste or spent wash arising from the manufacturing unit cause great menace, if released in the open. Silk dye waste effluents are more toxic to environment than the domestic sewage. Bhagalpur $\left(25^{\circ} 17^{\prime} \mathrm{N}\right.$ latitude and $86^{\circ} 83^{\prime} \mathrm{E}$ longitude) is endowed with age old silk fabric and yarn production units. Here, the manufacturers use mostly synthetic dye such as azo dyes as colorant for their products. Azo dye forms the largest and most important silk industry provides an important economic group of synthetic dyes (Mathur et al., 2005).

The heart is a major component of the body parts, which maintains blood flow in different part of body. The heart contain of four chambers through which the blood is pumped. The wall of the heart includes the cardiac muscle, a fibrous skeleton for attachment of the valves, and a specialized internal conducting system involved in the regulation of heart rate.

This study was therefore designed to investigation the effect of Moringa oleifera on silk dye waste effluent induced heart in male mice Mus musculus.

\section{Materials and Methods}

\section{Animals}

Experiment was performed on 6 to 8 weeks old healthy laboratory inbreed mice Mus musculus weighing about 30-35 grams. The animals were obtained from University Department of Zoology, Bhagalpur. Mice were reared and maintained at the animal house of University Dept. of Zoology, T.M. Bhagalpur University, and Bhagalpur under standard conditions and fed with nutritional diet and water.

\section{Collection of plant material}

Moringa oleifera leaf powder has been procured from own home product (with the help of ECHO Technical Note, By Beth Doerr and Lindsay Cameron, 2005, North Fort Myer, FL 33917, USA) Bhagalpur, Bihar, India.

\section{Collection of silk dye waste}

Silk dye waste effluents were collected directly from discharge point of silk dye industries of Nathnagar, Bhagalpur at regular interval.

\section{Experimental design}

The mice were divided into 5 groups of 8 animals each. Gr-I (control mice), Gr-II (mice treated with $50 \%$ silk dye waste), Gr-III (mice treated with $100 \%$ silk dye waste), Gr-IV (mice fed with $50 \%$ dye treated with $M$. oleifera leaves powder), Gr-V (mice fed with $100 \%$ dye treated with $M$. oleifera leaves powder).

\section{Dosage}

The control group was given normal food and water. Silk dye waste was administered orally $2 \mathrm{ml} /$ day (Chaurasia et al, 2005) group II and III for 30 and 60 days duration. M. oleifera leaf powder was also fed orally $300 \mathrm{mg} / \mathrm{kg}$ b.w to both the group IV and V for 30 and 60 days exposure as per the method suggested by Chatterjee et al, 2013.

\section{Biological assays}

Histopathological study of heart tissue.

\section{Tissue processing and staining}

After 30 and 60 days of experiment, mice were sacrificed and their organs were 
removed, were fixed in fixative and paraffinised, Haematoxylin-Eosin stained section of heart tissue were observed under light microscope (Pears, 1985) on 40X magnification.

\section{Results and Discussion}

\section{Histopathological observation on heart tissue}

Histopathological study on the heart tissue of control (Group-I) mice showed normal layer of epicardium, myocardium, endocardium and connective tissues in blood vessels (Fig. 1). In case of Group-II treated with 50\% silk dye waste at 30 days show that the decrease of myocardium thickness, disrupted connective tissue of cardiac muscle (Fig. 2). Group-IV treated with Moringa oleifera leaves powder at 30 days showed improvement in myocardium layer and connective tissue of cardiac muscle (Fig. 3). Group-III treated with $100 \%$ silk dye waste at 30 days showed the disrupted of epicardium and myocardium layer and also seen degenerated of connective tissue in blood vessels (Fig. 4). Group-V treated with $M$. oleifera leaf extract at 30 days showed connective tissue in blood vessels regeneration, also seen mitigation the layer of endocardium and myocardium (Fig. 5). In case of Group-II treated with $50 \%$ silk dye waste at 60 days showed endothelial cells and collagenous fibers were disrupted (Fig. 6). Group-IV treated with Moringa oleifera leaf extract at 60 days showed; more or less repair the endothelial cell and collagenous fibers of endocardium (Fig. 7). In case of Group-IV treated with $100 \%$ silk dye waste at 60 days showed disrupted epicardium and myocardium layer, also seen damage of subendocardial layer and thickness of collagenous fibers (Fig. 8). In case of Group$\mathrm{V}$ treated with $M$. oleifera leaf extract at 60 days showed the repair mechanism in epicardium and myocardium but not completely look like of normal tissue architecture, mitigation also seen in subendocardial layer and thickness of collagenous fibers (Fig. 9).

Figure.1 Photomicrograph of heart tissue section of mice showed, normal histoarchitecture (x40, H\&E)

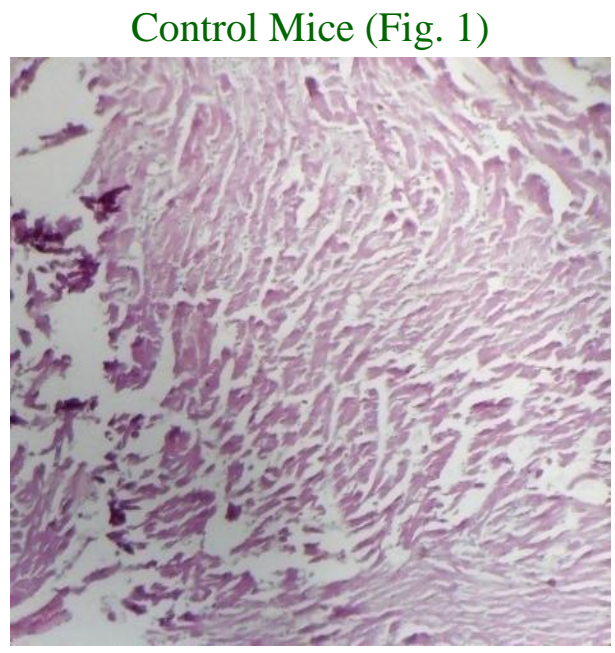


Fig.2 Photomicrograph of heart tissue section of mice showed, disrupted myocardium layer and connective tissue (x40, H\&E). Fig.3 Photomicrograph of heart section of mice showed, regeneration of myocardium and connective tissue (x40, H\&E). Fig.4 Photomicrograph of heart section of mice showed degenerated connective tissue and disrupted endocardium (x40, H\&E).

Fig.5 Photomicrograph of heart section of mice showed, mitigation of endocardium and myocardium (x40, H\&E)

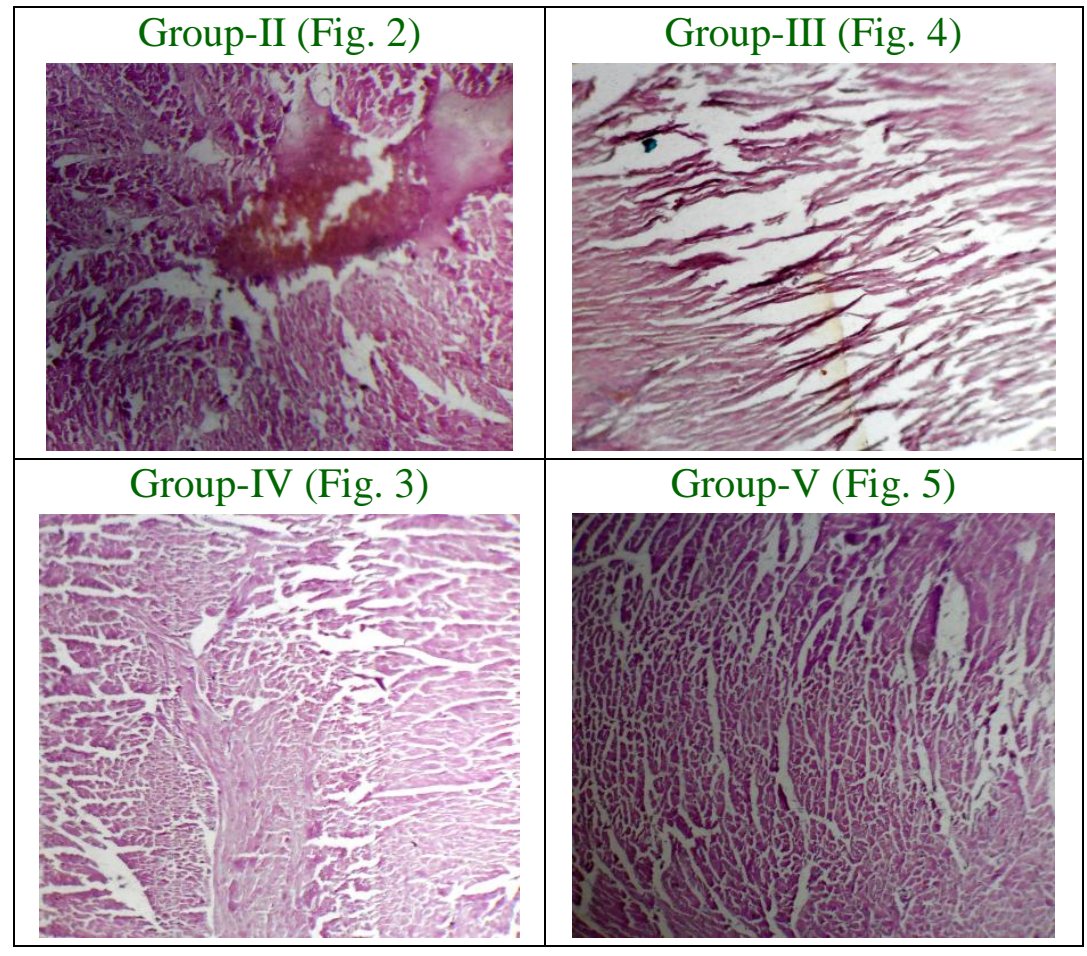

Fig.6 Photomicrograph of heart section of mice showed, endothelial cells and collagenous fibers also disrupted (x40, H\&E). Fig.7 Photomicrograph of heart section of mice showed, repair the endothelial cell and collagenous fibers of endocardium (x40, H\&E). Fig.8 Photomicrograph of heart section showed, disrupted of myocardium and epicardium, and damaged collagenous fibers thickness (x40, H\&E). Fig.9 Photomicrograph of heart tissue section of mice showed, more or less normal architecture of heart tissue, mitigation in subendocardial layer and thickness of collagenous fibers (x40, H\&E)

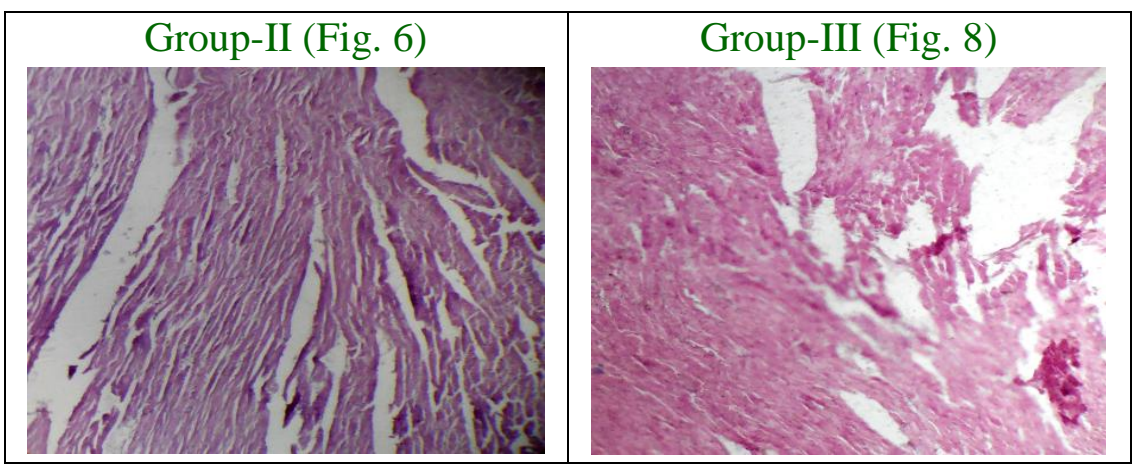




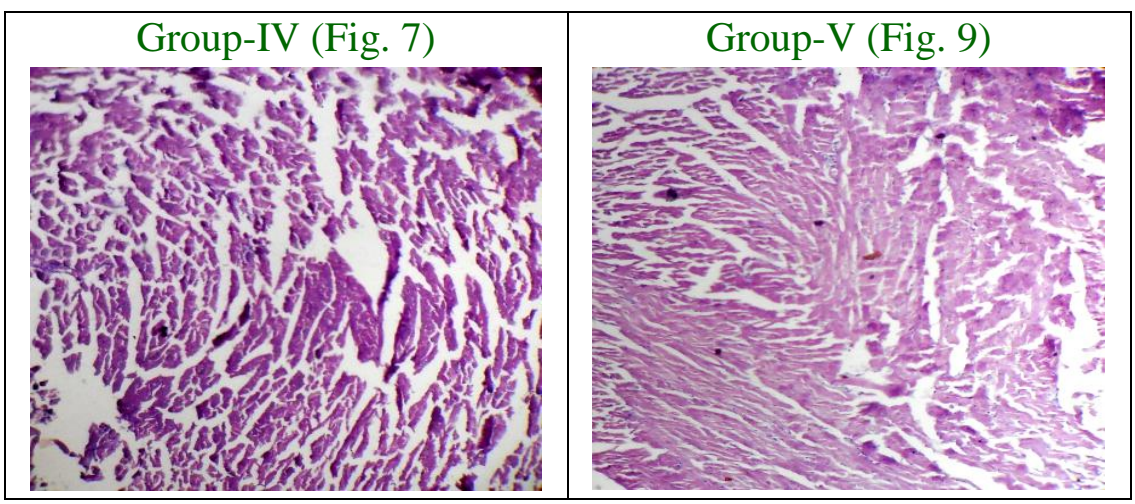

In the present experimental study were investigated, the histopathological effects of silk dye waste effluent on mice heart tissue and their significant mitigation using Moringa oleifera leaf extract. Some scientist provides that the triggering mechanism of macrophage accumulation is the result of cardiac afadin deficiency that increased the expression of the macrophage attracting cytokine MCP-1 (Kuwahara et al., 2004 and Sawaya et al., 2009). Ligation of the left anterior descending coronary artery in mice induces a large myocardial infarction that comprises $50 \%$ to $60 \%$ of the left ventricle (Jacob et al., 2012 and Gordts et al., 2013). The occurrence of ventricular rupture in the first 2 weeks after myocardial infarction in mice in frequent (Dart et al., 2005 and Muthuramu et al., 2013). Kiriazis et al in 2005 reported that the complication of myocardial infarction is strain dependent and occur significantly more often in male mice than in female. Serina, $K$ in 2017 reported that toxicity of silk dye wastes on lung of Swiss albino male mice Mus musculus and its mitigation by using Moringa oleifera leaf extract. The thinking of disproportionate and dilation of the infarct segment not only induces myocardial rupture but is also a trigger for cardiac remodeling and for congestive heart failure (Eaton et al., 1979; Erlebacher et al., 1982; Bulkley et al., 1979 and Jugdutt et al., 1987). Excessive amount of collagen fibers in cardiac interstitial space impede coronary vasodilation, oxygen diffusion and electromechanical coordination between cardiomyocytes, causing contractile abnormalities (Rohr et al., 2009). Kasner et al., in 2011 and Lopez et al., in 2012, reported that the increase of collagen and its cross linking stiffen the left ventricle, impairing ventricular relaxation and filling. Toxicity impact of Silk dye waste effluent induced Histopathological changes in the Stomach and Intestine of Swiss albino mice Mus musculus and their mitigation using Moringa oleifera leaf powder (Khatun, 2017). Toxicity of silk dye waste on Swiss albino male mice of different histopathological section as stomach and intestine, lung, testis, liver and mitigation using $M$. oleifera leaf extract (Serina et al., 2017).

On the basis of above discussion histopathological observations and facts it can be concluded that the $M$. oleifera leaf powder significantly reduce the alteration arisen in damage of heart tissue section and associated structures in the toxicity impact of silk dyes waste effluent induced mice Mus musculus.

\section{References}

Rohr, S (2009): Myofibroblasts in diseased heart: new players in cardiac arrhythmias? Heart Rhythm 6, 848-856.

Kasner, M (2011): Diastolic tissue Doppler indexes correlate with the degree of collagen expression and cross-linking in heart failure and normal ejection 
fraction. J. Am. Coll. Cardiol. 57, 977985.

Lopez, B., Querejeta, R., Gonzalez, A., Larman, M. and Diez, J (2012): Collagen cross-linking but not collagen amount associates with elevated filing pressures in hypertensive patients with stage $\mathrm{C}$ heart failure: potential role of lysyl oxidase. Hypertension 60, 677683.

Kuwahara, F (2004): Hypertensive myocardial fibrosis and diastolic dysfunction: another model of inflammation. Hypertension 43, 739745.

Deshmane, S. I., Kremlev, S., Amini, S and Sawaya, B. E (2009): Monocyte chemoattractant protein-1: an overview. J. Interferon Cytokine Res, 29, 313-326.

Van Creayveld, E; Jacobs, F; Godts, S.C \& De Geest, B (2012): Low-density lipoprotein receptor gene transfer in hypercholesterolemic mice improves cardiac function after myocardial infarction. Gene Ther. 19, 860-871.

Gordts, S.C (2013): Beneficial effects of selective HDL-raising gene transfer on survival, cardiac function after myocardial infarction in mice. Gene Ther. 20, 1053-1061.

Khatun, S (2017): Toxicity impact of Silk dye waste effluent induced Histo pathological changes in the Stomach and Intestine of Swiss albino mice Mus musculus and their mitigation using Moringa oleifera leaf powder. Journal of Medical Science and Clinical Research, 5(3), pp-19306-19313.

Serina, K (2017): Toxicity of silk dye waste on lung of Swiss albino male mice Mus musculus and its mitigation by using Moringa oleifera leaf extract. International Journal of Current Advanced Research, 6(1): pp-26572660.

Caceres, A; Cabrera, O; Morales, O;
Mollinedo, P. and Mendia, P (1991): Pharmacological properties of $\mathrm{M}$. oleifera. 1: preminary screening for antimicrobial activity. Journal of Ethnopharmacology, 33(3):213-216.

Jahn, S.A.A. (1988): Using Moringa oleifera seeds as coagulant in developing countries. J Amer Water Works Assoc, 6:43-50.

Khatun, S. and Varma, M.C. (2017): Toxicity impact of silk dye waste effluent on reproductive system of Swiss albino male mice Mus musculus and mitigation of M. oleifera leaf extract. World J. Pharmacy and Pharmaceutic Sciences, 6(1):1621-1629.

Khatun, S. and Varma, M.C. (2017): Role of Moringa oleifera leaf extract on silk dye waste effluent induced histopathotoxicity on liver and testis of Swiss albino male mice Mus musculus. IOSR Journal of Pharmacy, 7(4): 1-7.

Kumar, N.A and Pari, L (2003): Antioxidant Action of Moringa oleifera Lam. against peroxidation in rats. $J$ Med Food, 6(3):255-259.

Lakshminarayana, R; Raju, M; Krishnakantha, T.P and Baskaran, V. (2005): Determination of major carotenoids in a few Indian leafy vegetables by high-performance liquid chromatography. Journal of Agricultural and Food Chemistry, 53(8):2838-2842.

Mathur, N; Mehta, M; Chaudhry, V (2005): Sperm abnormality Induction by Food colour metanil yellow. J. Ecolphysiol. Occup. Hlth; 5:157-160.

Meyer, U. (1981): Biodegradation of synthetic organic colorants. FEMS Symp, 12:371-385.

Mishra, R. K; Singh, S.K (2007): effect of aqueous leaf extract of $A$. indica on the reproductive organs in male mice. Ind. Jol. Of Exptl. Biol. 43:1093-1103.

Nambiar, V.S and Seshadri, S (2001): 
Bioavailability trials of $\beta$-carotene from fresh and dehydrated drumstick leaves (M. oleifera) in a rat model. Plant Food for Human Nutrition, 56(1):83-95.

Sanchez-Machado DL, Lopez-Cervantes J, Vazquez NJ, 2006. High-performance liquid chromatography method to measure $\alpha$ and $\gamma$-tocopherol in leaves flowers and fresh beans from $M$. oleifera. Journal of Chromatography A, 1105(1-2):111-114.

Serina, K. and Varma, M. C. (2016): Effect of
M. oleifera leaf extract on silk dye effluent affected haematological and biochemical parameter on Swiss albino male mice. Amer. Inter. J. Form, Appli and Natu. Sci, 14(1), pp.50-55.

Udupa, S.L; Udupa. A.L and Kulkrni, D.R. (1994): Study on the anti-inflammatory and healing properties of $M$. oleifera and marmelos. Fitoterapia, 65(2):119123.

\section{How to cite this article:}

Serina Khatun. 2018. Effect of Moringa oleifera Leaf Extract on Histopathology of Heart Tissues on Silk Dye Waste Effluent Induced Swiss Albino Male Mice Mus musculus. Int.J.Curr.Microbiol.App.Sci. 7(02): 2094-2100. doi: https://doi.org/10.20546/ijcmas.2018.702.249 